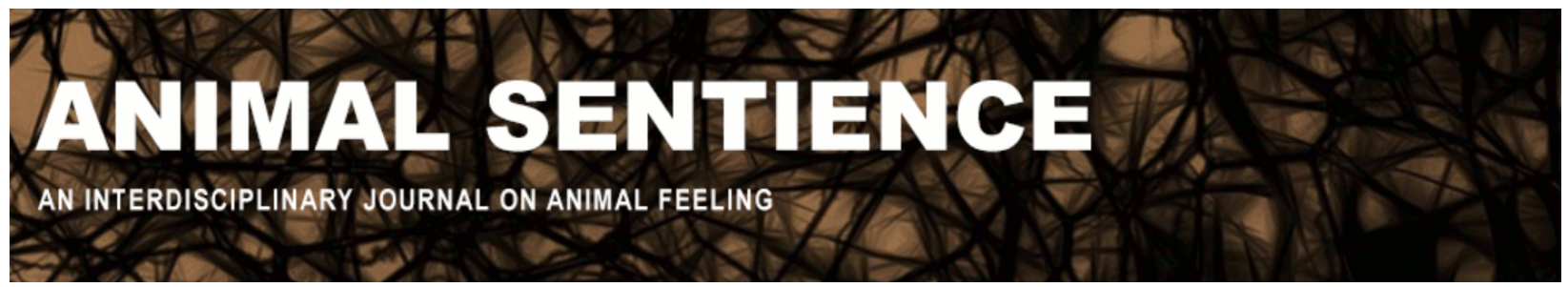

Webster, John (2019) Sentient animals do not just live in the present. Animal Sentience 25(10)

DOI: $10.51291 / 2377-7478.1443$

Date of submission: 2019-05-13

Date of acceptance: 2019-05-20

(c)

This article has appeared in the journal Animal

Sentience, a peer-reviewed journal on animal

cognition and feeling. It has been made open access,

free for all, by WellBeing International and deposited

in the WBI Studies Repository. For more information,

please contact

wbisr-info@wellbeingintl.org.

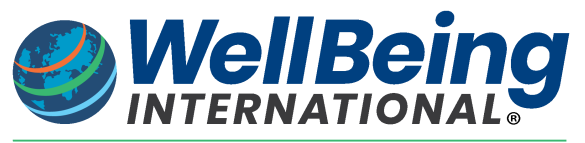

SOLUTIONS FOR PEOPLE, ANIMALS AND ENVIRONMENT 


\title{
Sentient animals do not just live in the present
}

\author{
Commentary on Marino \& Merskin on Sheep Complexity
}

\author{
John Webster \\ Bristol Veterinary School, University of Bristol, UK
}

\begin{abstract}
Sheep are particularly well-equipped with the cognitive and emotional skills appropriate to their phenotype and natural environment. These include spatial memory, the benefits of safety in numbers, and the ability to recognise special individuals in large flocks by sight and by sound. Marino \& Merskin's target article reviews convincing evidence on whether sheep are more or less clever than other mammalian species. Sheep are very good at being sheep. But sentient animals do not just live in the present. Their emotional state is not simply dictated by events of the moment. If they learn, they can cope; if not, they can experience chronic, nonadaptive stress. This is the big welfare problem.
\end{abstract}

John Webster is a veterinarian and Emeritus Professor of Animal Husbandry at the University of Bristol, UK. His early years were mostly concerned with the nutrition and environmental physiology of ruminants. More recently he took the first steps to establish a group now internationally recognised as the Bristol Centre for Animal Behaviour and Welfare. His most memorable contribution to the animal welfare debate has been the exposition of the concept of the 'Five Freedoms'. Website

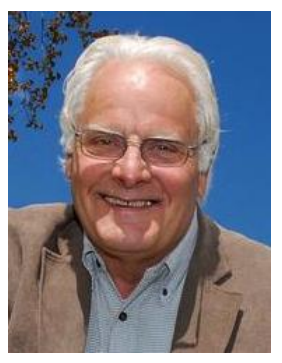

The mind of any sentient species evolves to cope with its environment in a way most appropriate to its phenotype. It is both anthropocentric and arrogant to assume that the cleverness of an animal species can be measured by comparing its behaviour to our own. Different species inhabit different worlds and give priority to different skills. Marino \& Merskin's (2019) (M\&M) excellent review begins with a brief historical review of human perception of sheep as 'dumb animals' largely arising from this anthropocentric fallacy. They then proceed to a thorough review of good recent science that provides ample evidence in support of a conclusion that would not have surprised Darwin. Sheep are very good at being sheep.

Sheep are a species that graze in flocks. They are subject to predation and have limited defences. The skills they need most include recognition of danger and safety in numbers, combined with a well-developed ability to recognise individual family and friends within large groups that look and sound similar (to us). Their fitness is further enhanced by an acquired knowledge of what is best to eat, what is most nutritious, what plants are poisonous and, indeed, what plants may be therapeutic. It is also essential to remind ourselves that no animal is at its most rational when under severe stress, as occurs too often during human/sheep interactions.

$M \& M$ review the evidence on sheep behaviour, cognition and emotion in the context of the classical concepts of animal psychology, for example, cognitive planning based on experience 
and learning, spatial memory, visual recognition, expressions of emotion, emotional communication and contagion, and cognitive bias (optimism v. pessimism) as a result of emotional experience. The spatial memory of sheep is excellent, and their facial recognition is amazing. They can recognise and remember hundreds of different sheep faces from photographs or even fragments of photographs. M\&M don't consider what is, in my experience, an even more important skill, namely, sound recognition. I have watched and heard ewes respond (only) to the call of their own lamb in flocks of over 500 . I have seen flocks grazing by a busy road respond (only) to the unique (to them) sound of the farmer's Land Rover bringing them feed. I would have welcomed more on food selection in sheep. Clearly, they recognise different flavours but these are only signals. Food selection is strongly influenced by the remembered consequences of how they feel in the hours after eating. Avoidance of plants that make them feel ill is hardly surprising, but there is evidence to show that sheep select, for example, high sugar grasses in the afternoons when sugar content is highest, high protein plants (e.g., clovers) and possibly anthelmintic (high tannin) plants when debilitated by parasitism.

$M \& M$ survey evidence of a wide range of emotional expressions in sheep ranging from fear to pleasure. Lambs are among the most playful of farmed species. Ewes, perhaps, act more like worried mothers. Fear is a highly developed, and highly necessary, emotional response in sheep. The subtle developments of this basic response, such as emotional communication and contagion, are vital to a species that depends for survival on safety in numbers. The most frightening experiences for a sheep are isolation and the unknown (neophobia).

The most valuable conclusion to be taken (or reinforced) from this review is one not special to sheep. Sentient animals do not just live in the present. Their emotional state is not simply dictated by events of the moment. Sentient animals learn and remember how well they can cope with the stresses of life. If they learn they can cope, they adapt and life gets easier. If they fail, then they can experience chronic, non-adaptive stress, from the anticipation of further events that will express itself within a spectrum that ranges from chronic anxiety to learned helplessness. This is the big welfare problem (Webster 2016).

\section{References}

Marino, L. and Merskin, D. (2019). Intelligence, complexity, and individuality in sheep. Animal Sentience 25(1)

Webster, J. (2016). Animal welfare: Freedoms, dominions and "a life worth living". Animals 6(6): 35. 